\title{
The Analysis of Learning Plan CONDitions for General COURSES (MKU) AT TIDAR UNIVERSITY BASED ON E-LEARNING
}

\author{
Hari Wahyono ${ }^{1)}$, Dzikrina Dian Cahyani ${ }^{2)}$ Delfiyan Widiyanto ${ }^{3)}$ \\ 1) Tidar University, Indonesia \\ E-mail: hariwahyono@untidar.ac.id \\ ${ }^{2)}$ Tidar University, Indonesia \\ E-mail: dzikrina@untidar.ac.id \\ 3) Tidar University, Indonesia \\ E-mail: delfiyanwidiyanto@untidar.ac.id
}

\begin{abstract}
This study aimed to review the condition of e-learning-based general course $(M K U)$ learning planning at Tidar University and its conformity with the vision and mission of Tidar University. Learning planning is an important aspect as a reference for implementation and reflection of learning. The type of this research is evaluation. Evaluation research is a research with systematic analysis using a five-step discrepancy model. A qualitative research approach was applied to analyze the data. Data were collected through interviews, observation, and documentation. The research subject is a lecturer at $M K U$ at Tidar University, while the object of research is $M K U$ Learning Plans (RPS). The research took place at Tidar University from January 2021-December 2021. The results showed that the e-learning-based general course learning planning at Tidar University had been prepared by the majority of course lecturers where the percentage of lecturers who compiled RPS was $97 \%$, and the rest by $3 \%$ no. In general, the preparation of learning plans has been categorized as good, namely the preparation of lecture materials, preparation of final skills, study materials for each meeting, learning methods, time allocation, student learning experiences, and the use of case study learning methods and team problem base learning. Weaknesses in learning planning were found at the stage of compiling graduate learning outcomes and subject learning outcomes that did not refer to the higher education curriculum in the era of the industrial revolution 4.0 and the standard of the Tidar University learning process. In addition, another drawback is that the preparation of the final capabilities of each meeting has not been formulated in accordance with the provisions. The preparation of assessment criteria and assessment indicators has not been systematically arranged where case study learning and team problem base learning have not been fully measured
\end{abstract}

Keywords: condition analysis; learning plans; semester learning plan

\section{INTRODUCTION}

General courses are subjects that must be taken by students of diploma and undergraduate programs. The juridical basis for administering general courses is the national education system regulations and university academic regulations. Based on article 37 paragraph (2) of Law no. 23 of 2003, it is stated that the higher education curriculum is obliged to provide lectures on Religious Education, Citizenship Education, and Indonesian Language. In Tidar University level regulations, it is stated that compulsory courses are classified into two consisting of national compulsory courses and university courses. Based on Article 14 paragraph (3) of the Rector of Tidar University Regulation No. 15/UN57/HK.01/2019 Regarding the Academic Guidelines of Tidar University, it is stated that the compulsory national general courses are Indonesian Language, Pancasila Education, Religious
Education, and Citizenship Education, while university compulsory courses include English and Entrepreneurship .

The implementation of $M K U$ at Tidar University contains special materials that support the vision and mission of Tidar University. This makes learning always have material inserts related to the vision and mission of Tidar University. General courses in this case are intended to give students character about the values of Tidar University. In addition, $M K U$ is a means to develop national identity, explore, and develop student potential.

General courses are managed by the Tidar University general course task force. Each course has a course coordinator or manager who is responsible for planning, monitoring implementation, and administering lectures. The general course task force $(M K U)$ is intended to manage the administration of courses at Tidar University. The $M K U$ task 
force works under the coordination of the $B A K P K$ Bureau (Academic Bureau for Student Planning and Cooperation).

The management of $M K U$ prior to the existence of the $M K U$ task force was left to the study program of each subject. However, this turned out to have an impact on $M K U$ whose management has not been optimal. The study program in this case has no full authority to manage $M K U$ because its role is to manage more on scheduling courses and distributing lecturers. In relation to the semester learning plan (RPS), the implementation of learning, and evaluation were also found to have not been managed optimally due to the limitations of the lecturers who are in charge of the courses. This is further exacerbated by the need for adaptation of existing technology in the form of e-learning which poses new challenges and problems.

Several weaknesses were found in the $M K U$ planning aspect at Tidar University. The diversity of the RPS of each supporting lecturer is known to be different from one another in the same subject. The different RPS include English, Indonesian, and entrepreneurship courses. Meanwhile, the RPS for the subjects of Pancasila Education, Citizenship Education, Islamic Religion, are all the same, although in accordance with the rules of RPS preparation, it is not necessarily good.

The semester learning plan is part of the $M K U$ learning plan at Tidar University. Learning planning is used to determine learning objectives. Planning in this case is in the form of a decision-making process as a result of thinking rationally about suggestions and certain learning objectives (Sanjaya, 2010).

Lesson plans become part of the teacher's skills. The UK and almost all countries in the world state that teachers need to have curriculum design and lesson planning skills (John, Peter D. 2007). The condition of facilities, students' abilities, and learning tools are taken into consideration in preparing lesson plans. This can then distinguish the learning plans of each school and class.

There are several learning tools that must be arranged in lesson planning. Hamalik (2010) suggests that the tools that must be prepared in learning are curriculum understanding, mastery of teaching materials, preparation of learning programs, implementation of learning programs and assessment of programs. This ability is needed to develop learning plans so that the plans that are prepared can be ensured of accuracy and conformity with learning objectives. Learning planning is understood as the process of preparing materials, media along with the use of approaches, learning methods, and time allocation in conducting learning (Majid: 2012).

The function and purpose of the formulation of this learning plan is in the form of obtaining good quality learning. Learning planning is very necessary because it is related to learning improvement (Uno, 2012). Learning improvements can be made based on understanding the curriculum and learning objectives as well as the results of the evaluation of the implementation of learning that has taken place. In China, the development of lesson plans is carried out using good tools for personal reflection and collegial reflection (Shen, Jianping, et al. 2007).

Planning is important in the implementation of learning so that further analysis of the lesson plan is needed to determine the quality of learning and the stages of preparation. Analysis of the conditions for preparing semester learning plans will reveal the advantages and disadvantages of e-learning-based RPS (semester learning plans) in general courses at Tidar University. The purpose of this research is to see the condition of e-learning-based general course learning planning $(M K U)$ at Tidar University and its conformity with the vision and mission of Tidar University.

\section{MethodS}

This research is an evaluation research. Evaluation research is research in which a systematic analysis of planning, implementation, and reporting is carried out to help groups assess and increase the value or benefits of objects (Stufflebeam \& Shrinkfield, 1985). The evaluation model used is a discrepancy model with five steps (Fernandes, 1984). Condition analysis was also carried out to measure the advantages and disadvantages of $M K U$ learning planning. The result of the condition analysis is a comparison between performance and standards (Steinmertz, 1977).

In this study, a qualitative research approach was used to analyze the data. The research data were collected through interview, observation, and documentation techniques. The research subject in this case is a lecturer in $M K U$ courses consisting of Pancasila Education, Citizenship Education, Religious Education, English, Indonesian and entrepreneurship courses. The object of research is RPS MKU. The research took place at Tidar University from January 2021-December 2021. The data analysis technique was carried out using data triangulation.

\section{RESULT AND DISCUSSION}

The data collected is data obtained from lecturers who teach courses in Pancasila Education, Citizenship Education, Religious Education, English, Indonesian and entrepreneurship. The results of data tabulation and data analysis related to the conditions of general course learning planning $(M K U)$ at Tidar University based on e-learning are as follows:

\section{A. Preparation of semester learning plans}

The preparation of lesson plans is carried out by each lecturer who is in charge of general courses. Based on data collection, the percentage of lecturers related to the preparation of the $R P S$ is as follows, 


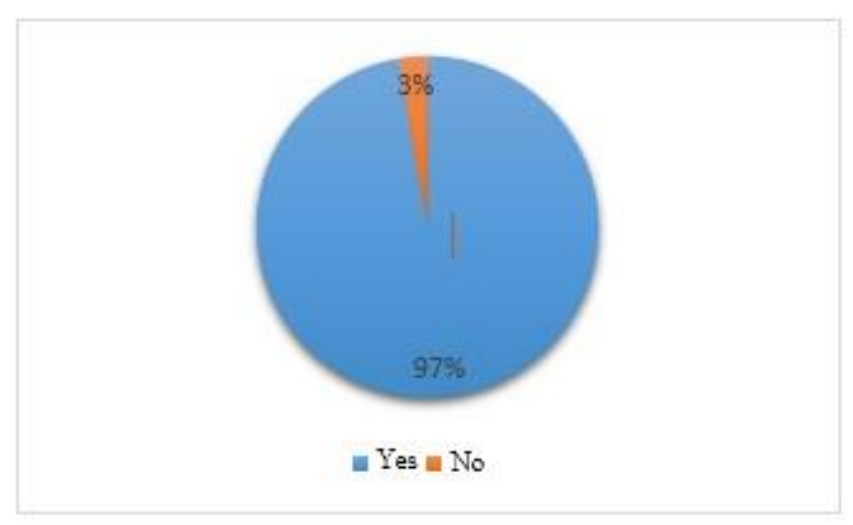

Fig 1. Percentage of lecturers who compile RPS

The majority of lecturers who teach $M K U$ courses at Tidar University have prepared RPS courses. Although there are several courses that are the same, the lecturers are still involved in the preparation of the RPS. In this case, as many as $3 \%$ of lecturers who did not participate in the preparation of the RPS since they have no free time due to busy work.

\section{B. The sources used in the preparation of the RPS}

Learning planning needs to be formulated systematically in order to produce learning planning tools. Systematic learning planning will facilitate the implementation of learning effectively and efficiently. The use of learning design models can support learning planning. Learning design is a systematic system in learning (Dick and Carey, 1985). Dick and Carey's (1985)expalined that learning design model approach is a systems approach that refers to a learning development system consisting of learner, teacher, material, and environmental components.

Each stage of learning is interrelated with each of the components of learning. The learning stage is measured according to national higher education standards. Each step of learning can be measured its success through the clarity of indicators.

There are various sources that can be taken for the preparation of the RPS. Based on data collection, it was found that the sources for the preparation of the RPS were reference books, curriculum, graduate achievements, learning processes, study program curriculum books, journals, the regulation of the Minister of Education and Culture of the Republic of Indonesia number 50 of 2015, the main performance indicators of higher education institutions, and RPS. long. Meanwhile, the sources for preparing the RPS that have not been used are the higher education curriculum in the industrial era 4.0 and the Tidar University standard.

\section{Preparation of Learning Outcomes in RPS}

Graduate learning outcomes are made by the study program. Based on the higher education curriculum in the industrial era 4.0 , it is stated that the learning outcomes of graduates must be compiled based on graduate tracking, stakeholder input, professional associations, scientific consortia, trends in scientific development, and evaluation results. Digital literacy skills, technological literacy, and awareness of the 5.0 industrial revolution are needed to support and face the industrial era 4.0. The curriculum needs to be created through collaboration between teachers and curriculum design. Collaboration between lecturers and the curriculum design team is used for curriculum development and professional improvement of teacher.

Learning outcomes which are the objectives of learning are listed in the RPS. The learning outcomes of graduates become the target of student abilities or skills that must be possessed after attending lectures. Referring to the results obtained from the data collected, it was found that the lecturers formulate the learning outcomes of graduates based on the depth of the material and according to the KKNI, National Higher Education Standards, study program curriculum guidelines, industry needs, curriculum analysis, Tidar University vision and mission, $M K U$ foundation and agreement from the $M K U$ lecturer team.

In addition, based on data collection, it is also known that to formulate graduate learning outcomes, the characteristics and uniqueness of universities, regional uniqueness, and Indonesia's uniqueness have not been added. Tidar University already has University learning standards that are used in the preparation of learning. Thus, it would be better if the characteristics and uniqueness of higher education, regionalism, and the uniqueness of Indonesia with the learning standards of Tidar University were also added to the learning outcomes of graduates.

There are points that must be included in the learning outcomes of graduates. Based on data collection, it was found that the points in the learning outcomes of graduates in RPS include work ethic, achievement motivation, independence, achievement and courage to make decisions, independent, creative, innovative, mindset abilities, attitudes, general and special skills, knowledge, and attitude.

If the formulation of graduate learning outcomes has been completed, then the next step is to develop course learning outcomes. The learning outcomes of graduates at Tidar University are considered to be general in nature, so that learning outcomes courses need to be made. The learning outcomes of the courses are then divided into subachievements of course learning as the final capabilities that are planned at each lecture meeting to meet the learning outcomes of graduates.

From the data collected, it was found that the way lecturers compile general course learning outcomes is by dividing graduate learning outcomes into general course learning outcomes, based on the KKNI and national higher education standards and taking into account the graduate profile of the study program, discussions and FGDs with the $M K U$ lecturer team as well as lowering the national standards of higher education in accordance with the characteristics of the study program.

Lecturers who teach courses are known to have compiled course learning outcomes by deriving them from graduate learning outcomes. The method used to formulate course learning outcomes in this case is by discussing between the FGD and the $M K U$ support team. The results of the 
preparation of course learning outcomes are in accordance with graduate learning outcomes.

\section{Preparation of the lecture materials for each meeting in the RPS}

The $M K U$ lecture meeting at Tidar University is divided into 14 meetings with one mid-semester examination and one end-semester examination. Lecturers share material at each meeting as a step to achieve graduate learning outcomes and courses. After the learning sub-outcomes of the course have been compiled, it is continued by formulating the final abilities where the course material will then be delivered. The material to be delivered refers to the sub-achievements of general course learning to support the learning outcomes of subjects and graduates.

Based on data collection, it was found that the way the lecturers divided the lecture material at each meeting was to adjust the learning outcomes to the expected final abilities of each meeting through discussions between lecturers based on the learning outcomes of the courses and lesson plans made.

Lecturers of general courses are known to have compiled the material presented at each meeting by referring to the subject learning sub-achievements and final abilities. The way the lecturer arranges the material presented at each meeting is through discussion between lecturers who are in charge of the same general course. However, some lecturers are still found not to fully understand so that the preparation is based on the old RPS.

\section{E. Preparation of the expected final abilities in the RPS}

The preparation of the final ability is carried out based on the sub-achievements of the course learning. Each suboutcome learning subject is used as a reference in compiling the expected final abilities from each meeting. The final ability of each subsequent meeting is used as the basis to support the achievement of the learning objectives of the course.

Based on the data collection conducted, it was found that the final learning ability of each meeting was prepared by the lecturer based on the curriculum of the study program, study materials, books, discussion with fellow lecturers, student needs, assessment criteria, and level of understanding. The results of the research data analysis show that the lecturers in charge of the courses have not compiled the final abilities of each meeting according to the provisions, where the majority of the lecturers prepare them using study materials, assessment criteria, and the level of student abilities. This may have an impact on the suitability and success of course learning outcomes.

\section{F. Preparation of study materials for each meeting in the RPS}

The study material for each meeting is related to the final ability of each meeting. Based on the results of the data collected, it was found that lecturers of study materials for each meeting were formulated based on reference books, modules, scientific journals, mass media, syllabus, graduate learning outcomes, course learning outcomes, national higher education standards, and discussions with other lecturers. The subjects of Pancasila Education, Citizenship Education, Religious Education, and Indonesian Language already have their own material guides when presented in lectures, so the majority of lecturers will use these references. However, the weakness of the reference is the absence of the unique characteristics of the university.

Furthermore, general English and Entrepreneurship courses also do not have national references so that lecturers are required to have more innovation and creativity. The preparation of study materials at each meeting is not in accordance with the uniqueness of the university, and the contents are still said to be too general.

Based on the results obtained from data collection, it is known that the points formulated by the lecturer in the study in the RPS are in the form of teaching media, teaching materials every week, following curriculum guidelines, references to higher education standards, breadth of material, and materials used for lectures.

\section{G. Determination of learning methods in RPS}

The characteristics of the material can determine the method used for the learning method. In addition, the learning method applied is based on the abilities expected in a learning stage. The results obtained from data collection revealed that the lecturer determined the learning method for each meeting based on higher education standards, discussions, material characteristics, study materials and expected final abilities, conformity with the main university performance indicators, academic rules, student circumstances, and level of material difficulty.

The existence of regulations from the ministry of education and higher education with higher performance indicators also influences the use of learning methods that will be applied. The general course lecturer has determined the learning method in accordance with the provisions. Thus it can be said that the learning method has been determined properly.

\section{H. Determine the time allocation in RPS}

The RPS has also determined the time allocation needed for the implementation of lectures. Determination of the time allocation is based on the weight of the lecture. The time allocation for each semester credit unit is 50 minutes. In other words, each credit will be multiplied by 50 minutes.

Based on the data collection conducted, it was found that the determination of the time allocation for lectures was determined by referring to the weight of credits, learning objectives, study materials, learning experiences, indicators, academic regulations, and graduate learning outcomes. Lecturers who teach general courses based on research results are known to have determined the time allocation by following the applicable academic provisions and guidelines. All lecturers have planned the time allocation properly and correctly.

\section{Preparation of the student learning experiences in RPS}

The form of student learning experience is stated in the tasks that must be done by them in one semester. The 
assignments given to students are intended so that they have the ability to achieve the expected learning objectives at each stage of learning.

Based on data collection, it was found that the points formulated by the lecturers on the student learning experience, include the specified abilities so that students are able to complete the tasks given, creative thinking skills, assignments, student involvement, learning activities carried out, and learning objectives.

Based on the results of the research, it was found that the lecturers who teach general courses have arranged student learning experiences in the form of assignments well. The preparation of assignments is also considered to be appropriate according to the provisions in the learning experience.

\section{J. Preparation of the assessment criteria and indicators in the RPS}

Assessment is one of the series in the implementation of learning. Black and William (2012) explained that assessment is the main part that supports and measures learning objectives. The assessment report will show the learning success achieved. A good assessment involves all aspects, starting from planning, managing, and assessing to measuring and reporting the learning outcomes carried out (Deluca, et. al, 2016: 3). Therefore, each stage of learning planning needs to be considered and systematic.

Tidar University has guidelines for the weighting of course assessments in theory and practice. This provision governs all courses at Tidar University. In this case, lecturers need to arrange grids, instruments, and scores for each question.

The data collected shows that the lecturer prepares the assessment criteria and indicators in the RPS by referring to the suitability of the study materials, learning methods, expected final abilities while considering study materials based on the learning outcomes of the courses, depending on the method and type of task, level of understanding and cognitive abilities, and student experience.

According to research results, it is known that the lecturers who support general courses have prepared the assessment criteria in a planned way in the RPS. However, one weakness was found in the form of the unsystematic assessment of the process and learning outcomes that were compiled. In addition, some lecturers were found to still use lecture material as a reference, not on final abilities in lectures so that the representation of course learning achievements could not be measured in the assessment. Assessment of learning processes and outcomes using case study learning methods and team problem base learning has also not been measured and evaluated.

Based on data collection, the points that must be included in the assessment criteria and indicators are the assessment of learning processes and outcomes, the final abilities achieved, basic understanding, and an overall adjusted assessment. The points in the assessment are complete and technically good in preparation. However, the assessment tool document that has not been compiled is recommended to be compiled immediately.

\section{$K$. The use of Case study learning methods and Team problem base learning in RPS}

The main performance indicators in universities provide a necessity for learning to use case study learning methods and team problem base learning. Based on data collection from general course lecturers, the findings obtained are as follows.

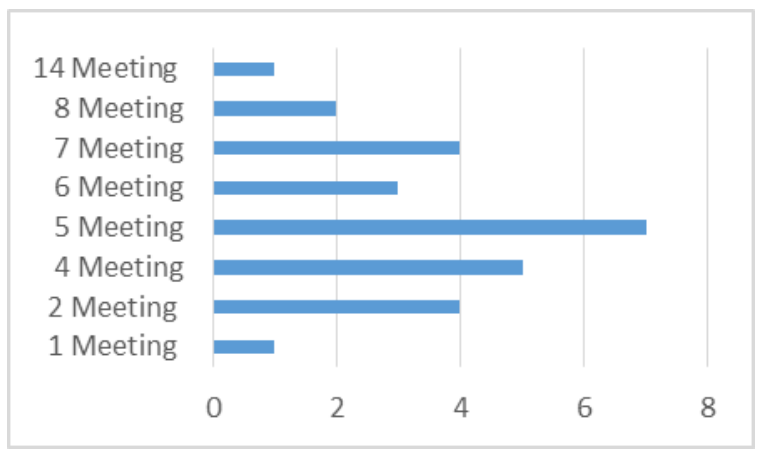

Fig. 2 Plans for using the case study method

All lecturers were found to have planned a case study learning model. Lecturers who support general courses have planned lectures using the case study method in more than one meeting where most of them have prepared a case study learning model for 5 meetings. This is categorized as good, considering the characteristics of the material and the final ability of each meeting are not necessarily suitable for using the case study learning method.

On the use of the team problem base learning method by the general course lecturer, the findings obtained are as follows.

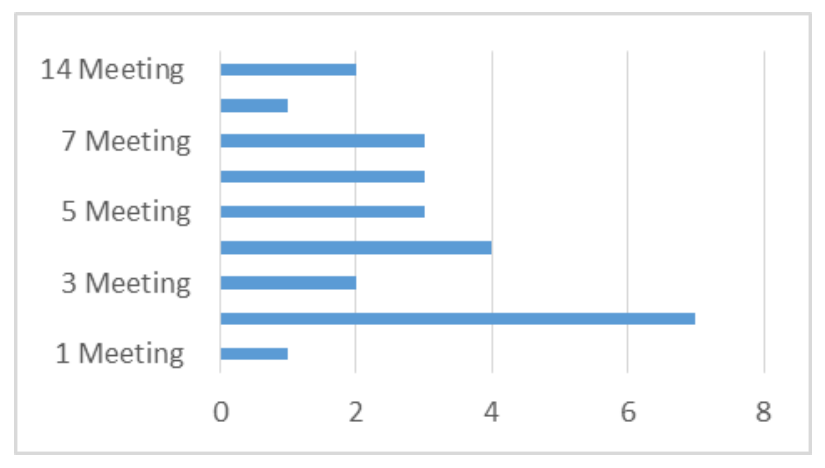

Fig. 3 Learning plans of Team problem base learning

In planning the learning of the problem base learning team, the lecturer has used this model. They have arranged this more than 1 meeting. The majority of lecturers used the team problem base learning model for 2 meetings. On the other hand, some of the shortcomings found are that lecturers use more case study methods and not many use team problem base learning because lecturers do not understand deeply about the method and face material difficulties or students' final abilities at each meeting are categorized as inappropriate for using the team problem base learning model. 


\section{CONCLUSIONS}

It is found that e-learning-based general course learning plans at Tidar University have been prepared by most of the course lecturers. The percentage of lecturers who compile the RPS based on research results is 97\%, while the remaining 3\% have not compiled RPS. The preparation of lesson plans in general is good. However, there are still some weaknesses in the preparation of graduate learning outcomes and subject learning outcomes that do not refer to the higher education curriculum in the industrial era 4.0 and the standard of the Tidar University learning process. This occurred because the graduate learning outcomes and learning outcomes are compiled based on the national curriculum and national higher education standards and have not been adjusted to the conditions of Tidar University. This causes efforts to support the vision and mission of Tidar University to be not optimal. The preparation of the final ability of each meeting has not been following the provisions. The preparation of assessment criteria and assessment indicators has not been systematically compiled where case study learning and team problem base learning have not been measured as a whole.

\section{REFERENCES}

Black, P \& William, D. (2012). Assessment for learning in the classroom. Dalam Gardner, J. (2012). Assesment and Learning. Great Britain: Sage Publication.

Deluca, C., Valiquette, A., Coombs, A., McEwan, D. L., \& Luhanga, U. (2016). Teachers approaches to classroom assesment: a large scale survey. Assesment in education: principles, policy \& practice. http://dx.doi.org/10.1080/0969594X. 2016. 1244514.

Dick, W and Carrey, L. (1985). The Systematic Design Instruction. Second edition. Glenview. Illinois: Scott., Foreman and Company

Direktorat Pembelajaran dan Kemahasiswaan Kementerian Riset Teknologi dan Pendidikan Tinggi (2019). Panduan Penyusuan Kurikulum Pendidikan Tinggi di Era Industri 4.0. Jakarta: Kementerian Riset, Teknologi, dan Pendidikan Tinggi Direktorat Jenderal Pembelajaran dan Kemahasiswaan.

Hamalik, Oemar. (1995). Kurikulum dan Pembelajaran. Jakarta: Bumi Aksara

Hamzah B. Uno. (2012). Model Pembelajaran Menciptakan Proses Belajar Mengajar yang Kreatif dan Efektif. Jakarta: PT Bumi Aksara.

John, Peter D. (2007). Lesson Planning and the students Teacher: Re-Thinking the Dominant Model. Jurnal Curriculum Studies. Vol. 38, No 4, PP 483-493

Majid, Abdul, (2012). Perencanaan Pembelajaran. Bandung: Rosda Karya.

Peraturan Rektor Universitas Tidar No. 15/UN57/HK.01/2019 Tentang Pedoman Akademik Universitas Tidar

Sanjaya, Wina. (2010). Perencanaan dan Desain Sistem Pembelajaran. Jakarta: Kencana Pradana Media Group.

Shen, Jinping. Sue Poppink, Yunhou Cui dan Gourui Fan (2007).Lesson Planning: A Practice of Professional
Responsibility and Development. Educational Horizons. Vol. 85, No. 4. pp. 248-258

Steinmetz, A. (1977). The discrepancy evaluation model. Dalam Merdaus, G. F., Scriven, M. F., \& Stufflebeam, D. L. Evaluation models: viewpoints on educational and human services evaluation second edition. New York: Kluwer Academic Publishers.

Stufflebeam, D.L \& Shinkfield, A.(1985). System evaluation. United State of America: Kluwer-Nijhoff Publishing.

UU No 20 tahun 2003 Tentang Sistem Pendidikan Nasional.

Voogt, J. M., Pieters, J. M., \& Handelzalt, A. (2016). Teacher collaboration in curriculum design teams: effects, mechanisms, and conditions. Education reseacrh and evaluation An international journal no theory and practice. $22 \quad$ (3-4). $121-140$. https://doi.org/10.1080/13803611.2016.1247725 